\title{
Dietary Patterns and Its Associations with Adipokines (Adiponectin and Leptin) among Adults: A Narrative Review
}

\author{
(Corak Pemakanan dan Kaitannya dengan Adipokin (Adiponektin dan Leptin)
}

dalam Kalangan Dewasa: Sebuah Ulasan Naratif)

\author{
NOR SYAMIMI ZAKARAI \& MOHD RAZIF SHAHRIL*
}

\begin{abstract}
To compile and analyse existing scientific evidence regarding the association of dietary patterns with adiponectin and leptin. Medline and PubMed electronic databases were searched for articles related to the association of dietary patterns with adiponectin and leptin from 2005 to 2015. Only full text articles using English as a language of publication were included. Studies were limited to the use of food frequency questionnaires in assessing dietary intake, factor analysis using principal component analysis, cluster analysis or reduced rank regression method in determining dietary pattern. A total of six relevant studies involving a total of 6467 subjects (47\% men and 53\% women) met the inclusion criteria from 1407 reviewed articles Twelve dietary patterns were extracted i.e. healthy pattern, meat and fat, sweet pattern, potatoes and refined grains, Japanese pattern, westernized pattern, mixed pattern, traditional pattern, vegetables, fruits and lean meat pattern, high alcohol, 'Izakaya' pattern and dieting. Two studies showed association with leptin which serum leptin concentration showed significantly higher in vegetables, fruits and lean meat compared to western pattern and lower circulating levels of leptin in westernized breakfast dietary pattern. Adiponectin concentration resulting significant positive relationship with fruits and vegetables, dieting, Japanese and healthy dietary pattern. Adherence to healthy dietary patterns plays an important role on serum adiponectin and leptin concentration. However, in most studies that resulted in a significant relationship, adiponectin, leptin and diet components were evaluated separately. Therefore, further well-designed studies were required to clarify the mechanism mediating relationship between dietary patterns and adipokines.
\end{abstract}

Keywords: Adiponectin; adult; dietary pattern; food-frequency questionnaires; factor analysis; leptin; principal component analysis

\section{ABSTRAK}

Mengumpul dan menganalisis data kajian saintifik yang sedia ada mengenai perkaitan di antara corak pemakanan dengan adiponektin dan leptin. Pangkalan data elektronik Medline dan PubMed telah digunakan untuk mencari artikel mengenai perkaitan corak pemakanan dengan adiponektin dan leptin dari tahun 2005 hingga 2015. Hanya artikel teks penuh dan yang meng gunakan bahasa Inggeris sebagai bahasa penerbitan diterima. Kajian telah terhad kepada penggunaan soal selidik kekerapan pengambilan makanan dalam menilai pengambilan makanan manakala dalam menentukan corak pemakanan kaedah yang digunakan haruslah faktor analisis, analisis komponen utama, analisis kelompok atau pengurangan kaedah regresi pangkat. Sebanyak enam kajian yang relevan dan memenuhi kriteria dari 1407 artikel yang telah dipilih. Kajian terpilih tersebut melibatkan seramai 6467 orang subjek (53\% wanita dan 47\% lelaki). Dua belas corak pemakanan yang dikaji ialah pemakanan sihat, daging dan lemak, gula dan manisan, kentang dan bijirin halus, pemakanan Jepun, pemakanan barat, pemakanan pelbagai, pemakanan tradisional, sayur-sayuran, buah-buahan dan corak pemakanan daging tanpa lemak, alkohol yang tinggi, dan diet 'Izakaya'. Dua kajian menunjukkan perkaitan dengan leptin dimana kepekatan serum leptin adalah jauh lebih tinggi dengan pengambilan corak pemakanan sayur-sayuran, buah-buahan dan daging tanpa lemak berbanding corak pemakanan barat. Kepekatan leptin dalam serum adalah lebih rendah pada pengambilan sarapan makanan barat. Manakala, kepekatan adiponektin menunjukkan perkaitan positif yang signifikan dengan pengambilan corak pemakanan tinggi buah buahan dan sayuran, corak pemakanan Jepun dan pemakanan sihat. Amalan corak pemakanan yang sihat memainkan peranan penting dalam mengawal kepekatan adiponektin dan leptin dalam serum. Walau bagaimanapun, dalam kebanyakan kajian yang menunjukkan hubungan yang signifikan bagi adiponektin dan leptin, komponen dietnya telah dinilai secara berasingan. Oleh itu, kajian yang lebih lanjut perlu dilakukan untuk menjelaskan hubungan mekanisme di antara corak pemakanan dan adipokin.

Kata kunci: Adiponektin; analisis komponen utama; corak pemakanan; dewasa; faktor analisis; leptin; soal selidik kekerapan pengambilan makanan 


\section{INTRODUCTION}

Adipokines is a generic term for $>50$ metabolically active factors which are expressed and secreted by an active endocrine organ - adipose tissue (Rokling-Andersen et al. 2007). Leptin, adiponectin, visfatin and tumour necrosis factor- $\alpha$ are among a wide range of adipokines that responsible for majority of endocrine, metabolic and vascular disorder related to obesity and obesity mediated adverse effects on glucose and lipid metabolism (JafariVayghan et al. 2015; Monzillo et al. 2003)adiponectin, resistin, tumor necrosis factor-alpha (TNF-alpha. Leptin concentration has been associated with a higher risk of type 2 diabetes, hypertension and chronic heart disease (Kashino et al. 2015). According to Jafari-Vayghan et al. (2015) the role in the regulation of food intake and energy expenditure is exerted by the leptin. Theoretically, adipose tissue will increase in mass and leads to obesity whenever energy intake exceeds the expenditure and a high serum leptin concentration detected in some obese subjects were related to leptin resistance. These are explained by the failure or decrease in leptin transport to the central nervous system of leptin receptors (Kopelman \& Grace 2004). Moreover, in hunger or fasting states, the concentration of leptin decreases. Hence, according to study done by Klok et al. (2007) on the role of leptin in the regulation of food intake, diet plays a direct and indirect role in the circulatory leptin concentration.

However, although adiponectin is also secreted from adipocytes, unlike leptin, its concentration is negatively correlated with body fat mass (Izadi \& Azadbakht 2015). Adiponectin has the anti-obesity, anti-diabetic, anti-cancer, anti-inflammation properties and a high concentration of serum adiponectin was also shown to be associated with insulin sensitivity (Izadi et al. 2012; Evagelidou et al. 2007; Izadi \& Azadbakht 2015). Besides similar to leptin, lifestyle-related factors such as physical activity and diet play a significant role in adiponectin concentration. Therefore, as adipokines; leptin and adiponectin are presumed to be biochemical predictors of many chronic non-communicable diseases such as diabetes, hypertension and coronary heart disease, it is crucial to discover modifiable factors including the pattern of diet that have an effect on these adipokines (Kashino et al. 2015).

Diet is a wide variety of foods containing complex combinations of nutrients and people consume a complex combination of food items. In nutrition epidemiology, the difficulties when searching for the impact of single nutrients have stimulated researcher's awareness to investigate the health effect of food item combinations that is food or dietary patterns (Barbaresko et al. 2013; Lucas et al. 2014; Martinez-Gonzalez \& Bes-Rastrollo 2014). Dietary pattern is among the important factors in the promotion and maintenance of good health throughout the entire course of life (Marchini et al. 2005). The analysis of dietary pattern has been implicated as an approach to examine diet-diseases relationship as it represents a broader picture of food and nutrient consumption and may thus be more predictive of diseases risk than individual food or nutrient (Shang et al. 2012). According to De Caterina et al. (2006), considerable evidence has accumulated that the dietary factors are the cornerstone in the prevention and treatment of lifestyle-related illness.

Adherence to healthy dietary pattern such as Mediterranean dietary pattern, fruits and vegetables dietary pattern and soy based dietary pattern previously displayed key role on protection against metabolic diseases, reduced risk of breast cancer and hip fracture (Catsburg et al. 2015; Dai et al. 2014; Mantzoros et al. 2006). In addition, based on Izadi and Azadbakht (2015) an increase in adiponectin or decrease in leptin concentration could be a mediator in differentiating between different types of dietary pattern. The present review aimed to gather available findings on the relationship between dietary pattern and adipokines i.e. adiponectin and leptin concentration among adults.

\section{METHODS}

\section{LITERATURE SEARCH}

Computerized databases of Medline and PubMed were used to conduct a literature search for scientific English articles published from 2005 to 2015 . The search was initiated using various combinations of keywords and terms related to dietary pattern, adiponectin and leptin as follows: 'diet' OR 'diet quality' OR 'dietary pattern' OR 'food pattern' OR 'eating pattern' OR 'food habits' OR 'food preferences' AND 'adiponectin', OR 'AdipoQ', OR 'ACRP30', OR 'apM-1' OR 'leptin', OR 'Ob Protein'.

\section{INCLUSION AND EXCLUSION CRITERIA}

Included articles must be measuring the association of dietary pattern and serum adiponectin or leptin concentrations among human adults subjects ( $>18$ years old). Studies that only examined relationship on special dietary components such as omega 3 fatty acid or high fat with serum leptin or adiponectin concentration instead of dietary pattern analysis were excluded. The eligible articles must be in English language, full-length and published in peer reviewed journals. Moreover, to be included in the present study, dietary intake must be obtained through food frequency questionnaires instead of other traditional methods such as $24 \mathrm{~h}$ diet recall or food record. Apart from that, studies that did not apply factor analysis specifically principal component analysis, cluster analysis, or reduced rank regression to identify dietary pattern were excluded.

\section{DATA EXTRACTION AND ANALYSIS}

Data were extracted for analysis of the methodology and outcomes from each study. The titles and abstracts of the identified articles were screened to eliminate duplicates and unrelated articles. Studies, which met the inclusion criteria were chosen and full-text was checked to determine articles for the final selection. Figure 1 explains the flow of literature search process. 
Objective

To compile and analyse existing scientific evidence regarding the articles of association o dietary pattern with adiponectin and leptin in adults

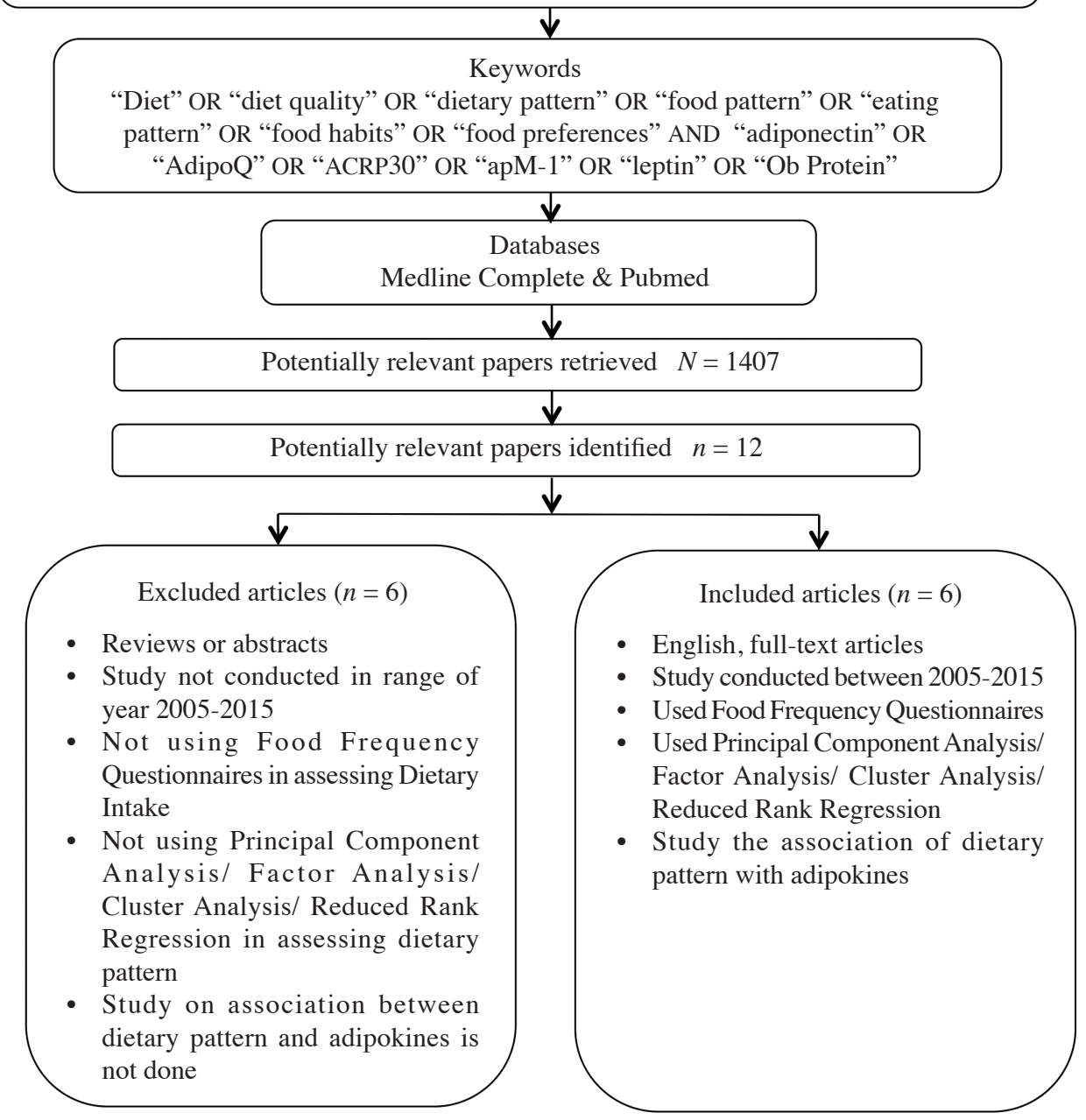

FIGURE 1 . The flow in the literature search process

\section{RESULTS}

\section{ARTICLES RETRIEVED}

A total of 1407 articles were reviewed according to the inclusion and exclusion criteria (Figure 1). Most articles were excluded due to lack of direct relation with the aim of this review; for example articles that not really assessing the relationship between dietary pattern with adiponectin or leptin and articles that only showing relationship on specific dietary components such as omega-3 fatty acids or high fat intake with adipokines concentration. Finally, a total of six relevant studies met the inclusion criteria which the association between dietary pattern and serum adipokines among adults were assessed throughout the study.

\section{SOCIO-DEMOGRAPHIC CHARACTERISTICS}

Socio-demographic characteristics of the respondents were summarized in Table 1. The present review includes a total of 6467 subjects involving $47 \%$ men and $53 \%$ women with majority representing non-institutionalized US civilian. All subjects were from 20 to 80 years of age and most have good health status with no illness except $2 \%$ of total subject who were patients with metabolic syndrome according to the National Cholesterol Education Program's Adult Treatment Panel III report (NCEP ATP III) criteria.

\section{RELATIONSHIP OF DIETARY PATTERN WITH ADIPOKINES (ADIPONECTIN AND LEPTIN)}

Table 2 presents the association of dietary pattern with serum adiponectin and leptin among six eligible articles. There were several types of dietary pattern category shown by all six studies including vegetables, fruit and lean meat, high alcohol, dieting, traditional Japanese, western, traditional English, sweet-fruit, 'Izakaya' (Japanese pub), westernized breakfast, mixed and healthy patterns. A positive correlation of adiponectin with fruit and vegetables, dieting, healthy and traditional Japanese dietary pattern was observed. However, negative association 
TABLE 1. Socio-demographic characteristics of the respondents enrolled in eligible articles $(n=6)$

\begin{tabular}{|c|c|c|c|c|c|}
\hline No. & Author (Year) & Country & Mean Age \pm SD [Range] & $\begin{array}{l}\text { Gender }= \\
\text { Numbers }\end{array}$ & Sample \\
\hline 1. & $\begin{array}{l}\text { Ganji et al. } \\
\text { (2009) }\end{array}$ & USA & $43.4 \pm 0.9$ & $\begin{array}{c}\text { Men }=1907 \\
\text { Women }=2102\end{array}$ & $\begin{array}{l}\text { Data from the third National Health and Nutrition } \\
\text { Examination Survey, 1988-1994; a sample } \\
\text { representative of the US civilian, non-institutionalized } \\
\text { population }\end{array}$ \\
\hline 2. & $\begin{array}{l}\text { Cassidy et al. } \\
\text { (2009) }\end{array}$ & UK & $47.8 \pm 12.3[18-80]$ & Women $=877$ & $\begin{array}{l}\text { Twins UK adult twin registry which were a sample } \\
\text { of the total population group who attended for } \\
\text { dual-energy x-ray absorptiometry scans and clinical } \\
\text { assessment between } 1996 \text { and } 2000\end{array}$ \\
\hline 3. & $\begin{array}{l}\text { Guo et al. } \\
\text { (2012) }\end{array}$ & Japan & $44.5[37.8-54.2]$ & Men $=702$ & $\begin{array}{l}\text { Subjects who had received lifestyle related illness and } \\
\text { health examinations (including a blood examination) } \\
\text { at Sendai Oroshisho Centre in } 2008\end{array}$ \\
\hline 4. & $\begin{array}{l}\text { Kashino et al. } \\
\text { (2015) }\end{array}$ & Japan & $43.4 \pm 10.7[20-65]$ & $\begin{array}{c}\text { Men }=296 \\
\text { Women }=213\end{array}$ & $\begin{array}{l}\text { Healthy full-time employees of two municipal offices } \\
\text { in north eastern Kyushu, Japan }\end{array}$ \\
\hline 5. & $\begin{array}{l}\text { Jafari-Vayghan } \\
\text { et al. (2015) }\end{array}$ & Iran & $36.7 \pm 8.8[25-50]$ & $\begin{array}{c}\text { Men }=75 \\
\text { Women }=75\end{array}$ & $\begin{array}{l}\text { Healthy subject randomly selected from a larger } \\
\text { study of } 670 \text { apparently healthy subject that aimed } \\
\text { to identify dietary patterns in Tabriz, Iran }\end{array}$ \\
\hline 6. & $\begin{array}{l}\text { Farhangi et al. } \\
\text { (2015) }\end{array}$ & Iran & $43.1 \pm 10.3[>20]$ & $\begin{array}{c}\text { Men }=23 \\
\text { Women }=134\end{array}$ & $\begin{array}{l}\text { Patients who have metabolic syndrome according to } \\
\text { the National Cholesterol Education Program's Adult } \\
\text { Treatment Panel III report (NCEP ATP III) criteria }\end{array}$ \\
\hline
\end{tabular}

was shown between adiponectin and traditional English, 'Izakaya' and western dietary pattern. Meanwhile, the concentration of leptin was increased with higher scores of vegetables, fruits, lean meat, mixed dietary pattern and decreased when consuming a westernized breakfast dietary pattern. Other types of dietary pattern including high alcohol and sweet-fruit pattern have no association with adiponectin and leptin concentration in the reviewed studies. The physiological relationship between dietary pattern, adipose tissue and adipokines (adiponectin and leptin) level summarized from all six studies included in this review is presented in Figure 2. The healthier choice of dietary pattern, e.g. fruits and vegetables, dieting, healthy, traditional Japanese and westernized breakfast might reduce adiposity which would increase adiponectin levels and at the same time lower the production of leptin, glucose and insulin level.

\section{DISCUSSION}

Regularly, the effects of single nutrients or foods have been focused in nutritional epidemiology studies. However, people consume a complex combination of food items that contains a variety of nutrients (Fung et al. 2001)little attention has been given to the effect of overall dietary patterns. Objective: Our objective was to examine the associations of 2 major dietary patterns, Western and prudent, with biomarkers of obesity and cardiovascular disease (CVD. Therefore, food and nutrient combination, interactions, inter-correlations and cumulative effects have to be used as an alternative approach to study overall diet instead of single dietary components. Apart from that, the use of dietary pattern analysis is important because the focus of the analysis is on the entire diet, rather than on just one food or nutrient and offers an additional dimension to examine the relationship between diet and disease risk (Frank et al. 2015)but has not been applied in sub-Saharan Africa. In a hospital-based case-control study for type 2 diabetes in Kumasi (diabetes cases, 538; controls, 668. According to Kashino et al. (2015) diet have been identified as one of the modifiable factors that may affect adipokines such as adiponectin and leptin which are the important biochemical indices that might have a role in health and disease. Hence, it is important to see the association of adiponectin and leptin concentration with different types of dietary patterns. Most evidence from eligible studies suggest a significant positive relationship between healthy dietary pattern such as fruits and vegetables pattern, Japanese pattern and dieting pattern with the concentration of adiponectin whereas high consumption of western dietary pattern lowers serum leptin concentration.

The present review involved studies from both western and Asian countries. Most sample were from western countries with $63 \%$ from non-institutionalized US civilian and $14 \%$ from TwinsUK adult registry. Whereas, Asian countries were represented by $11 \%$ who had received lifestyle related illness and health examination at Sendai Oroshisho Centre and another $8 \%$ from healthy full-time employee of two municipal offices in north eastern Kyushu, Japan. Apart from that, the remaining two studies were carried out at western Asia countries, involving 150 healthy subjects randomly selected from a larger study that aimed to identify dietary pattern in Tabriz, Iran and 157 patients who have metabolic syndrome according to the National 


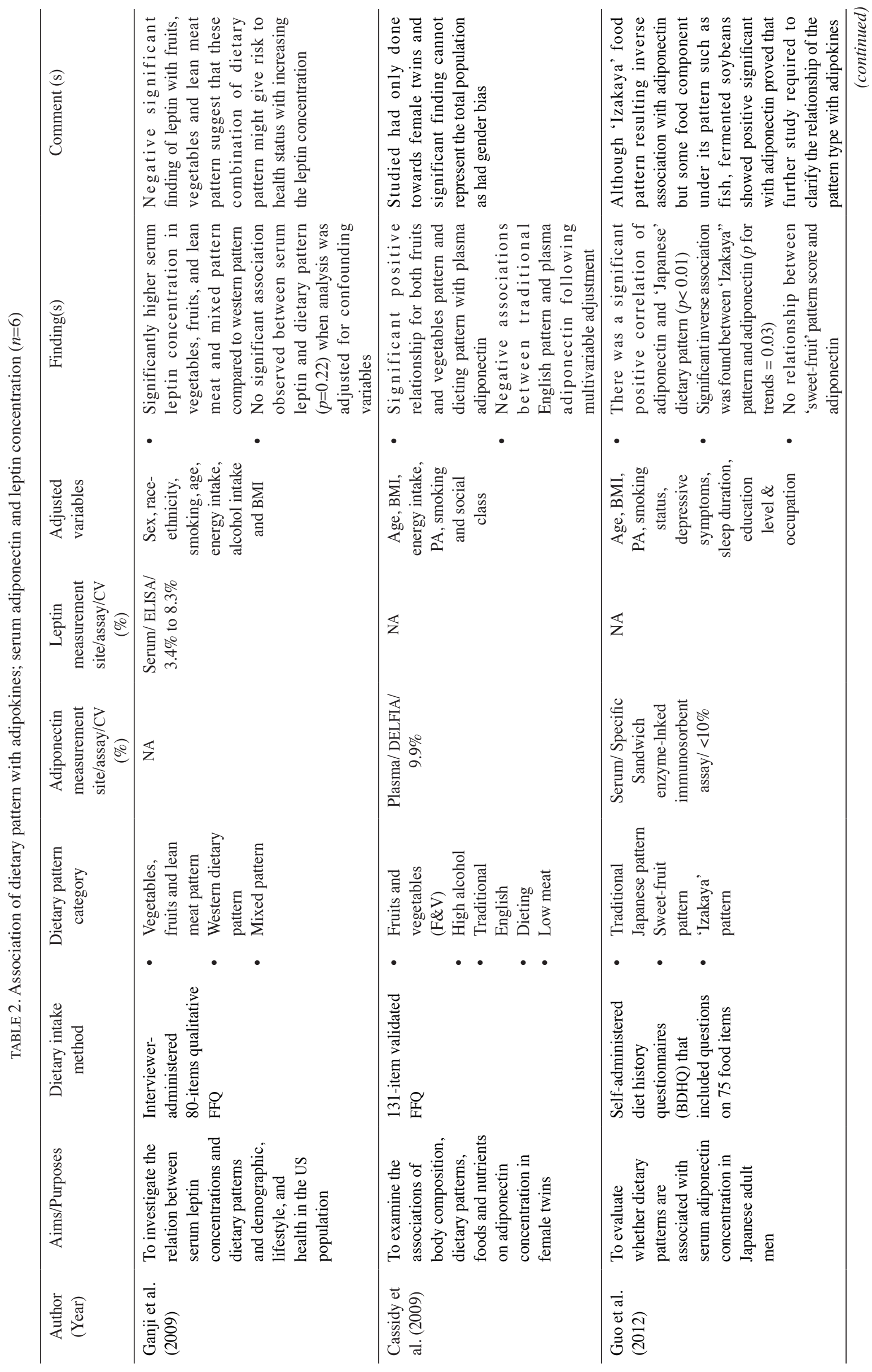




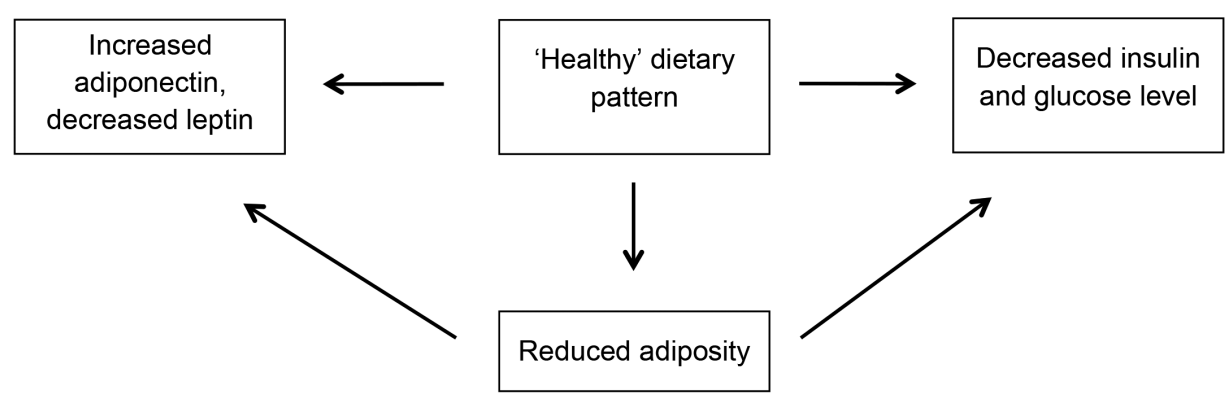

FIGURE 2. Relationship between 'healthy' dietary pattern, adipose tissue and adipokines (adiponectin and leptin)

Cholesterol Education Program's Adult Treatment Panel III. These 157 patients were the only unhealthy subject that involved in the present review. Therefore, even there were small numbers of eligible studies on the relationship of dietary pattern and serum adipokines concentration in these present review, but this review could represent global population as it involves both Asian and western residents.

This review shows that there are significant positive association between fruit and vegetable pattern, dieting pattern and Japanese pattern with adiponectin. Fruit and vegetable pattern is characterized by frequent consumption of fruit, allium and cruciferous vegetables and low intake of fried potatoes. Whereas those practicing dieting pattern frequently consumed low-fat dairy products, low-sugar soda and low intake of butter and sweet baked product. The same goes to Japanese pattern where it shows high consumption of vegetables, soybean, fish and green tea. However, mechanism underlying this relationship which either these components play the vital role on changes of adiponectin or the overall diet that exactly have the beneficial role on this effects are still unknown. Several studies had proved that high fruit and vegetable consumption have been allied with decreased occurrence and mortality from a variety of obesity-related diseases including Type 2 diabetes and cardiovascular diseases (Dauchet et al. 2004; Mozaffarian et al. 2004). Izadi and Azadbakht (2015) found several studies that have assessed the association between Mediterranean dietary pattern and adiponectin which characterized by consumption of high amount of whole grains, olive oil as well as moderate intake of fish and dairy products and lower consumptions of red meat, sweets and saturated fatty acids. These components had characterised Mediterranean diet as a low calorie diet with high amount of fibres, unsaturated fats and low glycaemic load. Their result showed that Mediterranean diet has beneficial effects on circulating of adiponectin. Moreover, previous study found that dietary pattern characterized by a high consumption of whole grains cereals and low fat dairy products was positively associated with adiponectin (Fargnoli et al.2008; Tsukinoki et al. 2005).

The present review also showed several association of dietary pattern with leptin concentration. One of the study showed that serum leptin concentrations were significantly lower among individual who consumed western diet compared to those who consumed vegetables, fruits, lean meat and mixed pattern diet (Ganji et al. 2009). This was consistent with findings by Kashino et al. (2015) which showed that westernized breakfast dietary pattern had lower circulating concentrations of leptin. The present review also showed that westernized breakfast pattern had high scores for confectioneries, bread, milk and yogurt but lower scores for alcoholic beverages and rice. This might be explained by foods and nutrients that contributed to the westernized breakfast pattern. Interestingly Akter et al. (2012) found a negative association between westernized breakfast pattern with prevalence of metabolic syndrome and high blood pressure which indicates westernized breakfast pattern might decrease risks of metabolic disease by reducing circulating leptin concentration.

\section{LIMITATIONS}

The main drawback of this review was the limited number of included articles. Our inclusion criteria indicated the use of food frequency questionnaires in dietary intake assessment and factor analysis, principal component analysis, cluster analysis or reduced rank regression analysis in detecting dietary pattern and its scores. In addition, most available studies have instead looked into association of adipokines with single food or nutrients rather than dietary pattern. These were the most crucial criterion that limit the number of eligible articles in the present narrative review. It was also noteworthy that the narrative method chosen to conduct this review has its own limitation where the systematic process of rating and selecting manuscript were not followed. Although the current review process includes specific inclusion and exclusion criteria for studies to be reviewed, selection bias is always possible due to the subjective nature of the narrative.

\section{CONCLUSION}

This review suggested that healthy dietary pattern characterized by high consumption of fruit and vegetables, low-fat dairy products, low-sugar soda and low intake of butter and sweet baked product such as dieting pattern 
and Japanese dietary pattern plays an important role in increasing serum adiponectin concentration. Whereas, leptin concentration decreased with increasing scores of westernized breakfast pattern. However, in most studies, the relationship of dietary pattern with adiponectin and leptin had evaluated diet components separately and the mechanisms underlying the association were not explained. Therefore, further well-designed studies were required to clarify the mechanism mediating relationship between dietary patterns and adipokines.

\section{ACKNOWLEDGEMENTS}

This work was supported by the Universiti Sultan Zainal Abidin via Dana Penyelidikan Universiti (DPU) UniSZA/2015/DPU/40.

\section{REFERENCES}

Akter, S., Nanri, A., Yi, S., Pham, N.M., Kurotani, K., Kimura, Y. \& Mizoue, T. 2012. Dietary patterns and C-peptide concentrations in a Japanese working population. Nutrition 28(9): 29-35.

Barbaresko, J., Koch, M., Schulze, M.B. \& Nöthlings, U. 2013. Dietary pattern analysis and biomarkers of low-grade inflammation: A systematic literature review. Nutrition Reviews 71(8): 511-527.

Cassidy, A., Skidmore, P., Rimm, E.B., Welch, A., Fairweathertait, S., Skinner, J., Burling, K., Richard, J.B., Spector T.D. \& Macgregor, A.J. 2009. Plasma adiponectin concentrations are associated with body composition and plant-based dietary factors in female twins. The Journal of Nutrition 139(2): 353-358.

Catsburg, C., Kim, R.S., Kirsh, V.A., Soskolne, C.L., Kreiger, N. \& Rohan, T.E. 2015. Dietary patterns and breast cancer risk: A study in 2 cohorts. The American Journal of Clinical Nutrition 101(3): 817-823.

Dai, Z., Butler, L.M., van Dam, R.M., Ang, L.W., Yuan, J.M. \& Koh, W.P. 2014. Adherence to a vegetable-fruit-soy dietary pattern or the Alternative Healthy Eating Index is associated with lower hip fracture risk among Singapore Chinese. Nutritional Epidemiology 144(4): 511-518.

Dauchet, L., Amouyel, P., Hercberg, S., Dallongeville, J., Mozaffarian, D., Pischon, T. \& Rimm, E.B. 2004. Dietary intake of trans fatty acids and systemic inflammation in. Journal of Nutrition 136: 606-612.

De Caterina, R., Zampolli, A., Del Turco, S., Madonna, R. \& Massaro, M. 2006. Nutritional mechanisms that influence cardiovascular disease. The American Journal of Clinical Nutrition 83(2): 421-426.

Evagelidou, E.N., Giapros, V.I., Challa, A.S., Kiortsis, D.N., Tsatsoulis, A.A. \& Andronikou, S.K. 2007. Serum adiponectin levels, insulin resistance, and lipid profile in children born small for gestational age are affected by the severity of growth retardation at birth. European Journal of Endocrinology 156(2): 271-277.

Fargnoli, J.L., Fung, T.T., Olenczuk, D.M., Chamberland, J.P., Hu, F.B. \& Mantzoros, C.S. 2008. Adherence to healthy eating patterns is associated with higher circulating total and high-molecular-weight adiponectin and lower resistin concentrations in women from the Nurses' Health Study. The American Journal of Clinical Nutrition 88(5): 1213-1224.
Farhangi, M.A., Jahangiry, L., Asghari-Jafarabadi, M. \& Najafi, M. 2015. Association between dietary patterns and metabolic syndrome in a sample of Tehranian adults. Obes. Res. Clin. Pract. 10(Supp. 1): S64-S73.

Frank, L.K., Jannasch, F., Kröger, J., Bedu-Addo, G., Mockenhaupt, F.P., Schulze, M.B. \& Danquah, I. 2015. A dietary pattern derived by reduced rank regression is associated with Type 2 diabetes in an urban Ghanaian population. Nutrients 7(7): 5497-5514.

Fung, T.T., Rimm, E.B., Spiegelman, D., Rifai, N., Tofler, G.H., Willett, W.C. \& Hu, F.B. 2001. Association between dietary patterns and plasma biomarkers of obesity and cardiovascular disease risk. The American Journal of Clinical Nutrition 73(1): 61-67.

Ganji, V., Kafai, M.R. \& McCarthy, E. 2009. Serum leptin concentrations are not related to dietary patterns but are related to sex, age, body mass index, serum triacylglycerol, serum insulin, and plasma glucose in the US population. Nutrition \& Metabolism 6(3): 1-12.

Guo, H., Niu, K., Monma, H., Kobayashi, Y., Guan, L., Sato, M., Minamishima, D. \& Nagatomi, R. 2012. Association of Japanese dietary pattern with serum adiponectin concentration in Japanese adult men. Nutrition, Metabolism and Cardiovascular Diseases 22(3): 277-284.

Izadi, V. \& Azadbakht, L. 2015. Specific dietary patterns and concentrations of adiponectin. Journal of Research in Medical Sciences 20(2): 178-184.

Izadi, V., Farabad, E. \& Azadbakht, L. 2012. Serum adiponectin level and different kinds of cancer: A review of recent evidence. ISRN Oncology 2012: 1-9.

Jafari-Vayghan, H., Tarighat-Esfanjani, A., Jafarabadi, M.A., Ebrahimi-Mameghani, M., Ghadimi, S.S. \& Lalezadeh, Z. 2015. Association between dietary patterns and serum leptinto-adiponectin ratio in apparently healthy adults. Journal of the American College of Nutrition 34: 49-55.

Kashino, I., Nanri, A., Kurotani, K., Akter, S., Yasuda, K., Sato, M. \& Mizoue, T. 2015. Association of dietary patterns with serum adipokines among Japanese: A cross-sectional study. Nutrition Journal 14(1): 58

Klok, M.D., Jakobsdottir, S. \& Drent, M.L. 2007. The role of leptin and ghrelin in the regulation of food intake and body weight in humans: A review. Obesity Reviews 8(1): 21-34.

Kopelman, P.G. \& Grace, C. 2004. New thoughts on managing obesity. Gut 53(7): 1044-1053.

Lucas, M., Chocano-Bedoya, P., Shulze, M.B., Mirzaei, F., Okereke, O.I. \& Ascherio, A. 2014. Inflammatory dietary pattern and risk of depression among women. Brain, Behavior, and Immunity 36: 46-53.

Mantzoros, C.S., Williams, C.J., Manson, J.E., Meigs, J.B. \& Hu, F.B. 2006. Adherence to the Mediterranean dietary pattern is positively associated with plasma adiponectin concentrations in diabetic women. The American Journal of Clinical Nutrition 84: 328-335.

Marchini, D.M.L., de Oliveira Latorre, M.do R.D., Eluf-Neto, J., Wunsch-filho, V. \& Fisberg, R.M. 2005. Identification of dietary patterns using factor analysis in an epidemiological study in sao paulo. Sao Paulo Medicine Journal 123(3): 124-127.

Martinez-Gonzalez, M.A. \& Bes-Rastrollo, M. 2014. Dietary patterns, Mediterranean diet, and cardiovascular disease. Current Opinion in Lipidology 25(1): 20-26.

Monzillo, L.U., Hamdy, O., Horton, E.S., Ledbury, S., Mullooly, C., Jarema, C. \& Mantzoros, C.S. 2003. Effect of lifestyle 
modification on adipokine levels in obese subjects with insulin resistance. Obesity Research 11(9): 1048-1054.

Mozaffarian, D., Pischon, T., Hankinson, S.E., Rifai, N., Joshipura, K., Willett, W.C. \& Rimm, E.B. 2004. Dietary intake of trans fatty acids and systemic inflammation. The American Journal of Clinical Nutrition 79: 606-612.

Rokling-Andersen, M.H., Reseland, J.E., Veierød, M.B., Anderssen, S.A., Jacobs, D.R., Urdal, P. \& Drevon, C.A. 2007. Effects of long-term exercise and diet intervention on plasma adipokine concentrations. The American Journal of Clinical Nutrition 86(5): 1293-301.

Shang, X., Li, Y., Liu, A., Zhang, Q., Hu, X., Du, S. \& Ma, G. 2012. Dietary pattern and its association with the prevalence of obesity and related cardiometabolic risk factors among Chinese children. PLoS One 7(8): 43183.

Tsukinoki, R., Morimoto, K.\& Nakayama, K. 2005. Association between lifestyle factors and plasma adiponectin levels in Japanese men. Lipids in Health and Disease 4: 27.
School of Nutrition and Dietetics

Faculty of Health Sciences

Universiti Sultan Zainal Abidin, Gong Badak Campus

21300 Kuala Nerus, Terengganu Darul Iman

Malaysia

*Corresponding author; email: razifshahril@unisza.edu.my

Received: 22 April 2016

Accepted: 23 February 2017 